\title{
Perancangan Sistem Pakar Penyakit Gigi Menggunakan Metode Forward ChainingPada Klinik Pratama Condet
}

\author{
Ahmad Ishaq ${ }^{1}$, Hesti Nugraheni ${ }^{2}$, Ahmad Al Kaafi ${ }^{3}$, Eva Rahmawati ${ }^{4}$, Nandang Iriadi $^{5}$, Achmad \\ Sumbaryadi ${ }^{6}$ \\ ${ }^{1}$ Universitas Bina Sarana Informatika \\ e-mail: ishaq@bsi.ac.id \\ ${ }^{2}$ STMIK Nusa Mandiri \\ e-mail: hestinugraheni18@gmail.com \\ ${ }^{3}$ Universitas Bina Sarana Informatika \\ e-mail: ahmad.akf@bsi.ac.id \\ ${ }^{4}$ STMIK Nusa Mandiri \\ e-mail: eva.ehw@nusamandiri.ac.id \\ ${ }^{5}$ Universitas Bina Sarana Informatika \\ e-mail: nandang.ndi@bsi.ac.id \\ ${ }^{6}$ Universitas Bina Sarana Informatika \\ e-mail: achmad.acs@bsi.ac.id
}

\begin{abstract}
Teeth are hard parts in the mouth. The tooth has a varied structure that functions as a cutter, renderer and food chewer. If the tooth is not cleaned after eating, it can cause bacteria to appear. Where these bacteria can damage teeth and cause a person to get dental disease. In addition to teeth is a tool for digestion of food, teeth are also a person's appearance. This display is very much needed and someone needs to meet face to face with other people. When cavities, will automatically reduce one's appearance. Moreover, cavities are accompanied by toothache, this can interfere with one's activities in doing work. expert system which is an artificial intelligence program that combines the base of the knowledge base with an inference system to imitate an expert. It is also a system that seeks to adopt human knowledge to computers, so that computers can solve problems as is usually done by experts. Forward Chaining is a decision-making strategy that starts from the fact to the final conclusion. Then monitoring uses an internet connection to connect to the web.
\end{abstract}

Key Word: Dental Disaese, Expert System, Forward Chaining, Web

\section{PENDAHULUAN}

Dengan melihat kepada kemajuan teknologi informasi di era globalisasi ini, penyediaan jasa berdasarkan keahlian yang dimiliki masing-masing orang menjadi lebih inovatif, lebih baik, lebih cepat dan sesuai dengan ekspektasi seiring berkembangnya zaman. Dengan adanya hal tersebut, bukan pula dijadikan sebagai ajang persaingan yang tidak sehat dengan saling menjatuhkan satu sama lain. Sebab yang perlu diperhatikan di sampingnya, disaat ilmu telah dikuasai, disaat itu juga harus dipublikasikan dengan tepat. Menjadi seorang yang dirujuk yang telah berpengalaman lama dan atau yang benarbenar bisa dipercaya.

Gigi merupakan bagian keras yang ada di dalam mulut. Gigi tersebut memiliki struktur bervariasi yang berfungsi sebagai pemotong, pengoyak dan pengunyah makanan. Apabila gigi tersebut tidak dibersihkan setelah makan, maka dapat menyebabkan munculnya bakteri. Dimana bakteri tersebut dapat merusak gigi dan menyebabkan seseorang terkena penyakit gigi.

Selain gigi merupakan alat pencernaan makanan, gigi juga merupakan sebagai tampilan seseorang. Tampilan ini sangat dibutuhkan dan diperlukan seseorang untuk bertatap muka dengan orang lain. Ketika gigi berlubang, otomatis akan mengurangi tampilan seseorang. Apalagi gigi berlubang yang disertai dengan sakit gigi, hal ini dapat menggangu aktifitas seseorang dalam melakukan pekerjaan (Irfan, Jusak, \& Saskianti, 2015).

Berdasarkan permasalahan yang ada dibutuhkan suatu aplikasi untuk membantu pengecekan masalah gigi, penyakit gigi lebih banyak 
diakibatkan oleh pola konsumsi yang tidak baik. Penyakit gigi mempunyai gejala-gejala awal sebelum penyakit tersebut menjadi semakin parah. Untuk mengetahui gejala-gejala tersebut, bisa dilakukan pemeriksaan rutin setiap 6 (enam) bulan sekali ke dokter gigi.

Selain itu, ada yang disebut dengan sistem pakar yaitu program kecerdasan buatan yang menggabungkan pangkalan basis pengetahuan dengan sistem inferensi untuk menirukan seorang pakar. Juga merupakan sistem yang berusaha mengadopsi pengetahuan manusia ke komputer, agar komputer dapat meyelesaikan masalah seperti yang biasa dilakukan oleh para ahli.

\section{METODE PENELITIAN}

\section{Penyakit Gigi}

Menurut (Mulyani \& SM, 2017) mengemukakan bahwa Gigi termasuk kedalam organ-organ tubuh yang ada pada wajah. Gigi adalah jaringan tubuh yang paling keras dibanding yang lainnya. Strukturnya berlapis-lapis mulai dari email yang sangat keras, dentin (tulang gigi) didalamnya, pulpa yang berisi pembuluh darah, pembuluh saraf, dan bagian lainnya yang memperkokoh gigi.

\section{Struktur Sistem Pakar}

Menurut Hartati dan Iswanti (2008:21) Sistem pakar merupakan sistem berbasis komputer yang menggunakan pengetahuan, fakta, dan teknik penalaran dalam memecahkan masalah, yang bisaanya hanya dapat diselesaikan oleh seorang pakar dalam bidang tertentu.

Menurut (Zulvian \& Verdi, 2017:15) dalam buku Pengantar Sistem Pakar Dan Metode terdapat 2 lingkungan yaitu lingkungan pengembangan dan lingkungan konsultasi sebagai berikut :

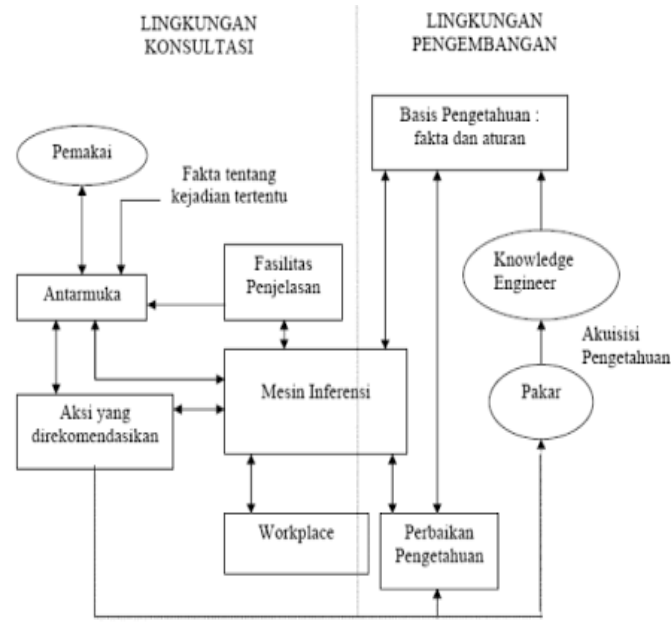

Sumber : (Zulvian \& Verdi, 2017:15)

Gambar 1. Komponen Dalam Sebuah Sistem Pakar

\section{Representasi Pengetahuan}

Menurut (Zulvian \& Verdi, 2017:23) representasi pengetahuan (knowledge representation) adalah cara untuk menyajikan pengetahuan yang diperoleh ke dalam suatu skema atau diagram tertentu sehingga dapat diketahui relasi suatu pengetahuan dengan pengetahuan yang lain dan dapat dipakai untuk menguji kebenaran penalarannya.

\section{Metode Inferensi}

Menurut Kusrini dalam jurnal (Tuslaela \& Permadi, 2018) inferensi merupakan proses untuk menghasilkan informasi dan fakta yang diketahui atau diasumsikan. Inferensi adalah konklusi logis (logical conclusion) atau implikasi berdasarkan informasi yang tersedia.

\section{Pohon Keputusan pada Sistem Pakar}

Menurut Merlina dan Hidayat dalam jurnal (Tuslaela \& Permadi, 2018) mengemukakan bahwa Pohon keputusan adalah sebuah jawaban akan sebuah sistem atau cara yang dikembangkan untuk membantu mencari dan membuat keputusan untuk masalah-masalah tersebut dan dengan memperhitungkan berbagai macam faktor yang ada di dalam lingkup masalah tersebut. Dengan pohon keputusan, manusia dapat dengan mudah mengidentifikasikan dan melihat hubungan antara faktor-faktor yang mempengaruhi suatu masalah dan dapat mencari penyelesaian terbaik dengan memperhitungkan faktor-faktor tersebut.Struktur.

\section{Objek Pakar}

Penulis melakukan wawancara kepada tiga dokter,pengolahan data diperoleh dari jawaban kuesioner yang diberikan kepada pakar, berikut ini merupakan biodata pakar tersebut, antara lain :
1. Nama
: drg. Rachmad

$\begin{array}{ll}\text { Umur } & \text { Farulsan Nasution } \\ \text { Jabatan } & : 29 \text { tahun } \\ \text { Pengalaman Kerja } & \text { : Dokter Gigi } \\ & \text { : Dokter Gigi }\end{array}$

2. Nama

$\begin{array}{ll}\text { Umur } & : 29 \text { tahun } \\ \text { Jabatan } & \text { : Dokter Gigi } \\ \text { Pengalaman Kerja } & : \text { Dokter Gigi Swasta } \\ & \text { dan Puskesmas }\end{array}$
3. Nama : drg. Mayani SK
Umur : 48 tahun
Jabatan : Dokter Gigi
Pengalaman Kerja : Dokter Gigi

\section{Hasil Wawancara Pakar}

Berdasarkan dari tiga orang pakar yang telah diwawancarai dan diminta untuk mengisikan kuesioner, di bawah ini merupakan kesimpulan yang telah diberikan oleh ketiga pakar tersebut, yaitu: 
1. Menurut drg. Rachmad Farulsan Nasution Penyakit Gigi adalah Rusaknya struktur gigi dan jaringan penyanggah gigi akibat oral hygine yang buruk/implikasi makanan sehingga terciptanya ekosistem bakteri.

Faktor Pemicu adalah oral hygine yang buruk, bakteri asam,trauma, konsumsi makanan yang lunak \& lengket \& manis.

Tindakan yang dilakukan adalah Emergency tretmen/debridement (jika trauma/sakit), dilakukan penempatan /perawatan sel akar/premetikasi, atau pencabutan, atau pembedahan.

\section{Pengertian :}

\section{A. Gingivitis}

Peradangan gusi akibat akumulasi plak/hormonal.

\section{B. Karang Gigi}

Terjadinya kristalisasi saliva \& penumpukan plak pada permukaan gigi.

\section{Periodontitis}

Kerusakan pada jaringan penyanggah gigi seperti gusi ligamen \& tulang.

\section{Abses Gigi}

Gusi bengkak akibat bakteri pada apikal gigi akibat gusi berlubang sehingga terjadinya caira prulen kekeringan(infeksi).

\section{E. Hyper Sensitive}

Terbukannya jaringan dentin pada gigi sehingga terjadi guncangan cairan pada tubuli dentin.

\section{F. Pulpitis}

Peradangan pulpa gigi.

G. Nekrosis Pulpa

Terjadinya pulpa pada gigi.

\section{H. Karies Gigi}

Gusi berlubang.

\section{Solusi :}

\section{A. Gingivitis}

Kontrol Plak, Sikat gigi 2x sehari, scalling.

B. Karang Gigi

Kontrol Plak, Sikat gigi 2x sehari, scalling.

\section{Periodontitis}

Kontrol Plak, Sikat gigi 2x sehari, scalling, kurerute/bedah periodental.

\section{Abses Gigi}

Drairase Abses, PSA (Perawatan Saluran Akar), hilangkan faktur etiologi.

E. Hyper Sensitive

Desentisasi (PlapisanTopical Flouridt).

F. Pulpitis

pencabutan gigi.

G. Nekrosis Pulpa

PSA (Perawatan Saluran Akar), pencabutan gigi.

\section{H. Karies Gigi}

pencabutan gigi.

2. Menurut drg. Danu Ega Arya Pratama

Penyakit Gigi adalah sakit yang disebabkan oleh rusaknya/kelainan pada jaringan struktur gigibmaupun jaringan pendukungnya berupa gusi, lidah, dan rongga mulut akibat adanya bakteri yang terbentuk karena akumulasi yang merusak struktur gigi \& mulut yang diperparah dengan pola hidup \& kebiasaan buruk dari individual tersebut yang tidak menjaga dengan baik kebersihan mulutnya.

Faktor Pemicu adalah oral hygine, impaksi makanan(makanan terselip) bakteri \& asam, konsumsi makanan \& minuman yang buruk, trauma oklusi(tekanan wajah besar), merokok, pola hidup yang buruk, tekanan psikologi(stress)

Tindakan yang dilakukan adalah mengobati keluhan utama terlebih dahulu, pembersihan karan gigi (jika gusi banyak kongusi gigi \& gingivitis), pencabutan gigi (bila gigi sudah goyang \& tinggal sisa akar), perawatan sel akar $\&$ premis (bila Gigi berlubang sudah dalam \& sakit namun masih bisa diperiksakan), penambalan gigi ( bila lubang tidak terlalu besar \& dalam), rujuk pasien pada dokter specialis untuk kasus tertentu (seperti penyakit mulut, pencabutan gigi geraham yang ringan dll)

\section{Pengertian :}

\section{A. Gingivitis}

Pembengkakan gusi \& meradang akibat okumulasi bakteri pada gusi yang membuat gusi gampang berdarah.

B. Karang Gigi

Penumpukan sisa-sisa makanan / debri pada gigi \& gusi (jaringan lunak).

\section{Periodontitis}

Rusaknhya jaringan pendukung gigi(gusi) karena bakteri \& juga penumpukan kalkulus yang menyebabkan mulai berkurangnyaperlekatan gusi pada gigi sehingga gusi turun/menyurut.

D. Abses Gigi

Bengkaknya gusi pada suatu gigi dikarenakan kuman/bakteri yang masuk dari Gigi berlubang hingga sampai pada saluran akar dan ujung akar gigi yang dimana antibodi/ sel darah kita melakukan reaksi perlawanan sehingga terciptakan cairan nanah (infeksi) yang menyebabkan pembengkakan suatu gigi.

E. Hyper Sensitive

Terbukannya jaringan dentin pada gusi seperti penurunan gusi pada bagian akar 
yang menyebabkan gigi menjadi lebih sensitif terhadap rangsangan.

F. Pulpitis

Peradangan pada pulpa gigi akibat gusi berlubang namun gigi masih bersifat vital.

G. Nekrosis Pulpa

Peradangan pada pulpa gigi akibat Gigi berlubang namun gigi sudah non vital \& biasanya pasien tidak merasakan sakit lagi.

H. Karies Gigi

Gigi berlubang .

Solusi :

\section{A. Gingivitis}

Kontrol plak, oral hygine, edukasi pasie,pembersihan karang gigi, pemberian saran pasta gigi \& obat kumur, scalling.

B. Karang Gigi Kontrol plak, oral hygine, scalling, DHE.

C. Periodontitis

Kontrol plak, scalling, kuretasi, bedah periodetal,DHE, bila sudh goyang dilakukan pencabutan.

D. Abses Gigi

Premed dengan antibiotik,painkiller, \& anti inflamasi, PSA,drainase, hilangkan etiologi, penambalan.

E. Hyper Sensitive

Deratisasi,tumpatan gigi.

F. Pulpitis

PSA, premed, tumpatan gigi.

G. Nekrosis Pulpa

PSA, premed,tumpatan gusi.

H. Karies Gigi

Penambalan gigi.

3. Menurut drg. Mayani SK

Penyakit Gigi adalah suatu kondisi dimana struktur gigi menjadi busuk oleh kebersihan mulut yang buruk yang menyebabkan rasa nyeri disekitar gusi dan rahang.

Faktor Pemicu adalah kebersihan mulut yang buruk, bakteri asam, trauma, mengkonsumsi makanan yang lunak manis \& lengket.

Tindakan yang dilakukan adalah penambalan atau sauran akar, pengobatan, pencabutan dan pembedahan.

\section{Pengertian :}

\section{A. Gingivitis}

Salah satu bentuk penyakit gusi dimana keadaan gusi merah dan meradang yang disebabkan karna kebersihan mulut yang buruk.

B. Karang Gigi
Tumbuhnya plak gusi yang mengeras dan membentuk kerak atau karang.

C. Periodontitis

Suatu infeksi gusi yang terisris yang merusak gusi dan dapat menghancurkan atau merusak tulang rahang.

D. Abses Gigi

Terbentuknya kantong atau benjolan berisi nanah pada gusi yang disebabkan oleh infeksi bakteri.

E. Hyper Sensitive

Suatu keadaan dimana gusi terasa sangat sensitive terhadap rangsangan dari luar gusi misalnya panas dingin yang diakibatkan oleh bagian gusi tidak terlindungi oleh email.

F. Pulpitis

Peradangan yang terjadi di pulpa gusi.

G. Nekrosis Pulpa

Kematian pulpa yang disebabkan oleh penipisan atau peradangan pulpa yang tidak dirawat.

H. Karies Gigi

Kerusakan struktur jaringan gusi yang disebabkan bakteri dan asam.

Solusi :

A. Gingivitis

Pencabutan, perawatan saluran akar gusi.

B. Karang Gigi

Pembersihan karang gigi, menjaga kebersihan mulut.

C. Periodontitis

Pengobatan, pembersihan karang gusi,root planning, pembedahan.

D. Abses Gigi

Pengobatan, perawatan saluran akar.

E. Hyper Sensitive

Menggunakan aqua pengurangi rasa sensitif pasta gigi, memperbaiki hub gigitan rahang atas \& bawah.

F. Pulpitis

Perawatan saluran akar, penambalan, pencabutan, pengobatan.

G. Nekrosis Pulpa

Pencabutan, perawatan saluran akar, pengobatan.

H. Karies Gigi

Penambalan, penggunaan fluoride, crows.

\section{Algoritma Sistem Pakar}

Algoritma merupakan alur dari sebuah program. Algorima ini digunakan untuk mempermudah dalam membaca program. Dalam merancang algoritma sistem pakar ini, aturan-aturan diuji satu demi satu dalam urutan tertentu. Saat tiap aturan diuji, sistem pakar akan mengevaluasi apakah kondisinya benar atau salah. Jika kondisinya benar, maka aturan itu disimpan kemudian aturan berikutnya diuji. Sebaliknya, jika kondisinya salah, aturan tidak 
disimpan dan aturan berikutnya diuji. Pada proses konsultasi sistem, sistem akan mengajukan beberapa pertanyaan yang harus dijawab oleh pengguna dengan menjawabnya "Ya" atau "Tidak". Semua jawaban disimpan ke dalam memori, proses pencarian dilakukan secara berurut dari simpul awal sampai akhir pertanyaan sampai mencapai tujuan. Berikut rancangan algoritma :

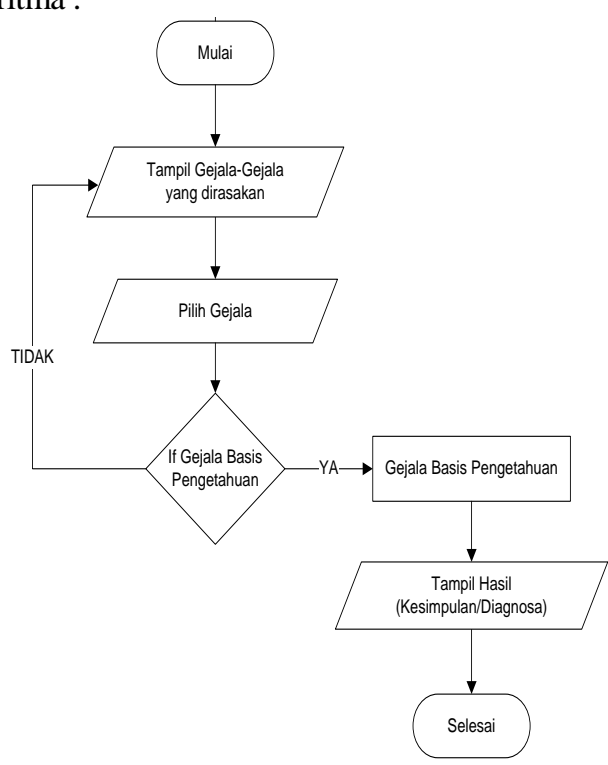

Gambar 2. Rancangan Algoritma

\section{Basis Pengetahuan}

Dalam perancangan sistem pakar diagnosa penyakit gigi, penulis melakukan observasi dan wawancara kepada para dokter gigi di Klinik Family Dental Care. Hal itu dilakukan untuk mendapatkan data penyakit-penyakit gigi yang sering ditangani. Berdasarkan data penyakit gigi tersebut, kemudian ditelusuri gejala-gejala yang dialami pasien pada saat menderita penyakit itu. Data gejala-gejala ini sangat penting dalam melakukan kesimpulan penyakit yang diderita pasien. Setelah itu dibuat penjelasan, penyebab, dan solusi mengenai penyakit-penyakit gigi, hel ini sangat berguna untuk menambah pengetahuan pasien mengenai penyakitnya. Data penyakit

\section{Tabel pakar}

Dalam perancangan sistem pakar mendeteksi penyakit gigi dan mulut, penulis melakukan tanya jawab dengan tiga dokter.

Tabel 1.Tabel Penyakit

\begin{tabular}{|c|l|}
\hline KODE & \multicolumn{1}{|c|}{ NAMA PENYAKIT } \\
\hline P01 & Abses Peripikal \\
\hline P02 & Gigi hipersensitif \\
\hline P03 & Gingivitis(Radang Gusi) \\
\hline P04 & Kalkulus(Karang Gigi) \\
\hline P05 & Karies Gigi \\
\hline P06 & Pulpitis \\
\hline
\end{tabular}

\begin{tabular}{|l|l|}
\hline P07 & Nekrosis Pulpa \\
\hline P08 & Periodontitis \\
\hline
\end{tabular}

Tabel 2. Tabel Gejala

\begin{tabular}{|l|l|}
\hline KODE & \multicolumn{1}{|c|}{ GEJALA } \\
\hline G01 & Sulit mengunyah \\
\hline G02 & Rahang menjadi membengkak \\
\hline G03 & Demam \\
\hline G04 & $\begin{array}{l}\text { Pembengkakan kelenjar getah bening } \\
\text { sekitar rahang atau leher }\end{array}$ \\
\hline G05 & Bau mulut tak sedap \\
\hline G06 & Rasa sakit atau nyeri di sekitar gigi \\
\hline G07 & Penipisan Email \\
\hline G08 & Gigi patah \\
\hline G09 & Gigi berlubang atau busuk \\
\hline G10 & $\begin{array}{l}\text { Denti menjadi terbuka memicu gigi } \\
\text { mudah sensitif }\end{array}$ \\
\hline G11 & Gusi yang menyusut \\
\hline G12 & $\begin{array}{l}\text { Pembengkakan atau peradangan pada } \\
\text { gusi }\end{array}$ \\
\hline G13 & Gusi mudah berdarah \\
\hline G14 & Bentuk gusi agak membulat \\
\hline G15 & Konsistensi gigi menjadi lunak \\
\hline G16 & Terdapat endapan plak \\
\hline G17 & Terdapat karang gigi \\
\hline G18 & Dentin terlihat \\
\hline G19 & Gigi terasa ngilu dan sensitif \\
\hline G20 & $\begin{array}{l}\text { Pulpa terinfeksi atau radang palpa } \\
\text { pul }\end{array}$ \\
\hline G22 & Sakit berdenyut tanpa rangsangan \\
\hline G23 & Pulpa mati rasa \\
\hline G25 & Ruang pulpa terbuka \\
\hline Gusi bengkak \\
\hline Gusi berwarna merah \\
\hline G26
\end{tabular}

Tabel 3. Tabel Solusi

\begin{tabular}{|c|c|}
\hline KODE & SOLUSI \\
\hline S01 & $\begin{array}{l}\text { Kontrol Plak, Sikat Gigi 2x Sehari, } \\
\text { Scalling, Oral Hygine, Edukasi Pasie, } \\
\text { Pembersihan Karang Gigi, Pemberian } \\
\text { Saran Pasta Gigi \& Obat Kumur, } \\
\text { Pencabutan, Perawatan Saluran Akar } \\
\text { Gusi. }\end{array}$ \\
\hline $\mathrm{S} 02$ & $\begin{array}{l}\text { Kontrol Plak, Sikat Gigi 2x } \\
\text { Scalling, Oehari, } \\
\begin{array}{l}\text { Pembersihan Karang Gigi, Menjaga } \\
\text { Kebersihan Mulut. }\end{array}\end{array}$ \\
\hline S03 & $\begin{array}{l}\text { Kontrol Plak, Sikat Gigi 2x Sehari, } \\
\text { Scalling, Kurerute/Bedah Periodental, } \\
\text { Kuretasi, Bedah Periodetal, DHE, Bila } \\
\text { Sudah Goyang Dilakukan Pencabutan. } \\
\text { Pengobatan, Pembersihan Karang Gusi, } \\
\text { Root Planning, Pembedahan. }\end{array}$ \\
\hline
\end{tabular}




\begin{tabular}{|c|l|}
\hline S04 & $\begin{array}{l}\text { Drairase Abses, PSA (Perawatan Saluran } \\
\text { Akar), Hilangkan Faktur Etiologi, } \\
\text { Premed Dengan Antibiotik Painkiller \& } \\
\text { Anti Inflamasi, Drainase, Penambalan, } \\
\text { Pengobatan. }\end{array}$ \\
\hline S05 & $\begin{array}{l}\text { Desentisasi (Plapisantopical Flouridt), } \\
\text { Tumpatan Gigi, Menggunakan Aqua } \\
\text { Pengurangi Rasa Sensitif Pasta Gigi, } \\
\text { memperbaiki hub gigitan rahang atas \& } \\
\text { bawah. }\end{array}$ \\
\hline S06 & $\begin{array}{l}\text { Pencabutan Gigi, PSA, Premed, } \\
\text { Tumpatan Gigi, Perawatan Saluran Akar, } \\
\text { Penambalan, Pengobatan. }\end{array}$ \\
\hline S07 & $\begin{array}{l}\text { PSA (Perawatan Saluran Akar), } \\
\text { Pencabutan Gigi, Premed, Tumpatan } \\
\text { Gusi, Pengobatan. }\end{array}$ \\
\hline S08 & $\begin{array}{l}\text { Pencabutan Gigi, Penambalan Gigi, } \\
\text { Penggunaan Fluoride, Crows. }\end{array}$ \\
\hline
\end{tabular}

Tabel 4. Tabel Pakar

\begin{tabular}{|c|c|c|c|c|c|c|c|c|}
\hline \multirow{2}{*}{$\begin{array}{c}\text { KOD } \\
\text { E }\end{array}$} & \multicolumn{7}{|c|}{ PENYAKIT } \\
\hline & P0 & P0 & P0 & P0 & P0 & P0 & P0 & P0 \\
\hline & 1 & 2 & 3 & 4 & 5 & 6 & 7 & 8 \\
\hline G01 & X & & & & & & & \\
\hline G02 & X & & & & & & & \\
\hline G03 & X & & & & & & & \\
\hline G04 & X & & & & & & & \\
\hline G05 & X & & & X & & & & X \\
\hline G06 & X & & & & & & & \\
\hline G07 & & X & & & & & & \\
\hline G08 & & X & & & & & & \\
\hline G09 & & X & & & X & X & X & \\
\hline G10 & & X & & & & & & \\
\hline G11 & & X & & & & & & \\
\hline G12 & & & X & & & & & X \\
\hline G13 & & & X & X & & & & \\
\hline G14 & & & X & & & & & \\
\hline G15 & & & & & & & & \\
\hline G16 & & & & X & & & & \\
\hline G17 & & & & X & & & & \\
\hline I8G18 & & & & & X & X & & \\
\hline G19 & & & & & X & X & & \\
\hline G20 & & & & & & X & & \\
\hline G21 & & & & & & X & & \\
\hline G22 & & & & & & & X & \\
\hline G23 & & & & & & & X & \\
\hline G24 & & & & & & & X & \\
\hline G25 & & & & & & & & X \\
\hline G26 & & & & & & & & X \\
\hline G27 & & & & & & & & \\
\hline SOLU & S0 & S0 & S0 & S0 & S0 & S0 & S0 & S0 \\
SI & 1 & 2 & 3 & 4 & 5 & 6 & 7 & 8 \\
\hline
\end{tabular}

Rule-rule Pada Pakar

Untuk mempresentasikan pengetahuan danmendapat solusi yang terbaik dari beberapa masalah penyakit gigi dan mulut, maka penulis membuat knowledge base atau rule base system pakar yang biasanya ditulis dalam bentuk jika-maka (IF-THEN) adalah sebagai berikut:

Rule 1 : Jika Sulit mengunyah Dan Rahang menjadi membengkak Dan Demam Dan Pembengkakan kelenjar getah bening sekitar rahang atau leher Dan Bau mulut tak sedap Dan Rasa sakit atau nyeri di sekitar gigi Maka penderita mengalami Abses Peripikal.

Rule 2 : Jika Penipisan Email Dan Gigi patah Dan Gigi berlubang atau busuk Dan Denti menjadi terbuka memicu gigi mudah sensitif Dan Gusi yang menyusut Maka penderita mengalami Gigi Hipersensitif.

Rule 3 : Jika Pembengkakan atau peradangan pada gusi Dan Gusi mudah berdarah Dan Bentuk gusi agak membulat Dan Konsistensi gigi menjadi lunak Maka penderita mengalami Gingivitis (radang gusi).

Rule 4 : Jika Bau mulut tak sedap Dan Gusi mudah berdarah Dan Terdapat endapan plak Dan Terdapat karang gigi Maka penderita mengalami Kalkulus (Karang gigi).

Rule 5 : Jika Dentin terlihat Dan Gigi berlubang atau busuk Dan Gigi terasa ngilu dan sensitif Maka penderita mengalami Karies Gigi.

Rule 6 : Jika Dentin terlihat Dan Gigi berlubang atau busuk Dan Gigi terasa ngilu dan sensitif Dan Pulpa terinfeksi atau radang pada pulpa Dan Sakit berdenyut tanpa rangsangan Maka penderita mengalami Pulpitis.

Rule 7 : Jika Gigi berlubang atau busuk Dan Pembusukan gigi Dan Pulpa mati rasa Dan Ruang pulpa terbuka Maka penderita mengalami Nekrosis Pulpa.

Rule 8 : Jika Bau mulut tak Sedap Dan Gusi bengkak Dan Gusi berwarna merah Dan Gusi mudah berdarah Dan Pembengkakan atau peradangan gusi Maka penderita mengalami Periodontitis.

Pohon Pakar Keputusan 


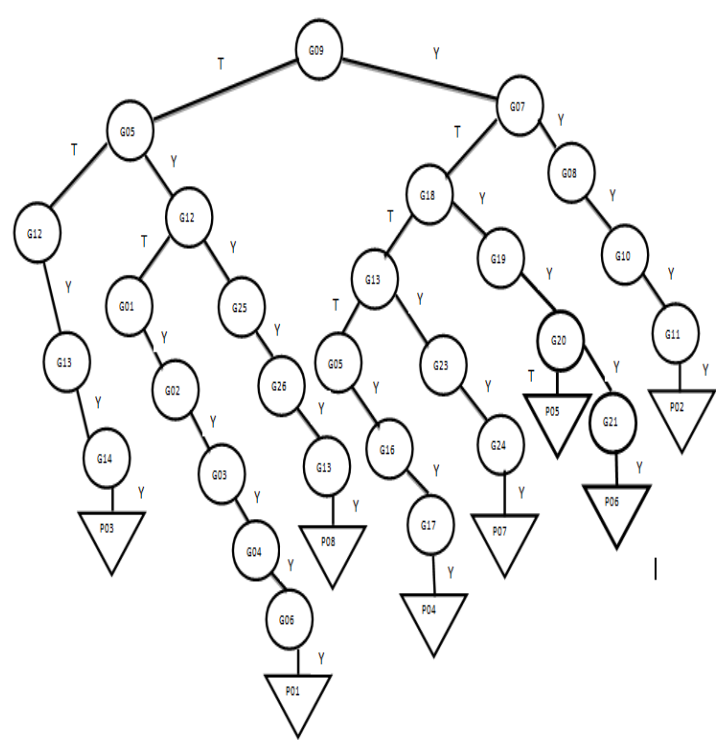

Gambar 3. Pohon Pakar Keputusan

\section{HASIL DAN PEMBAHASAN}

Use case diagram Halaman Pasien

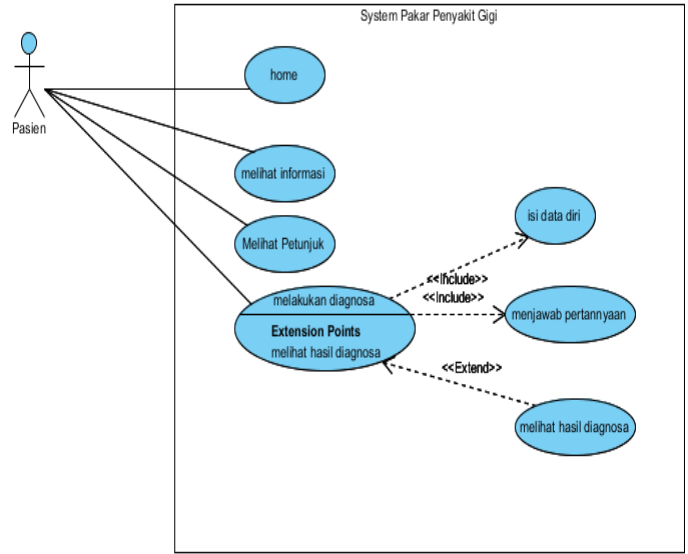

Gambar 4. Use case diagram Halaman Pasien

Entity Relations Diagram

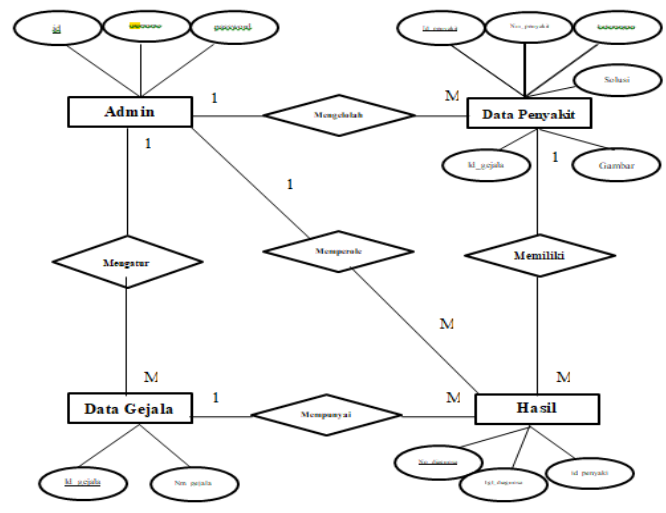

Gambar 4. Entity Relationship Diagram

Activity Diagram Halaman Data Penyakit

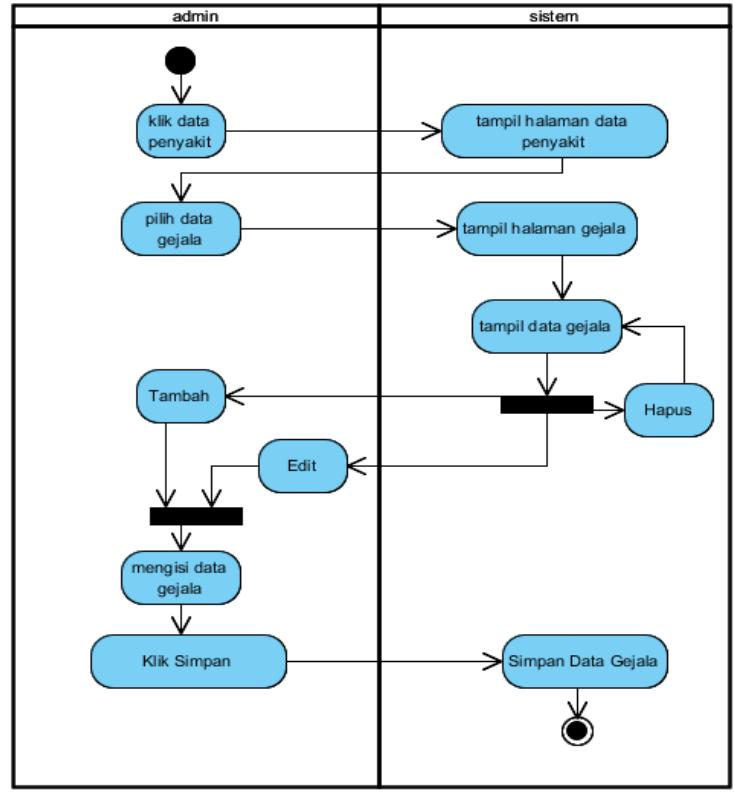

Gambar 4. Activity Diagram Halaman Data Penyakit

User Interface

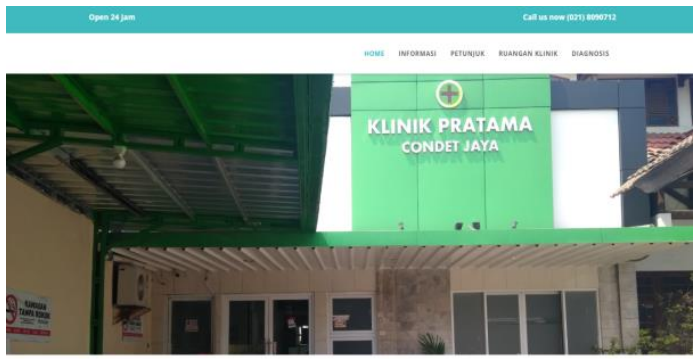

Gambar 4. User Interface

\section{KESIMPULAN}

Pemahaman mengenai Penyakit Gigi itu sangat penting karena apabila tidak segera ditangani dapat mengakibatkan bahaya kerusakan penyakit gigi semakin parah dan berlanjut untuk kedepannya.

Aplikasi sistem pakar ini dibuat agar mempermudah pasien dalam mendiagnosa dan mengetahui gejala penyakit gigi secara dini sehingga pengguna dapat mengetahui beberapa penjelasan penyakit gigi, faktor pemicu, dan memperoleh solusi dari penyakit gigi yang mereka rasakan sebelum berkonsultasi secara langsung.

Aplikasi ini dapat diakses dengan menggunakan device berbasis internet untuk mempercepat pencarian sehingga pemakai dapat menggunakan aplikasi ini sebelum menemui pakar atau dokter terkait. Guna untuk mengakses ilmu pengetahuan informasi perihal penyakit gigi.

\section{REFERENSI}

Herliana, A., \& Rasyid, P. M. (2016). Sistem 
Informasi Monitoring Pengembangan Software pada Tahap Development Berbasis Web. Jurnal Informatika, 3(1), 41 50.Retrieved from http://ejournal.bsi.ac.id/jurnal/index.php/ji/artic le/view/281/293

Hulliyah, K., Mintarsih, F., \& Kurniawan, B. (2010). DIAGNOSA PENYAKIT GIGI DAN MULUT DENGAN MENGGUNAKAN PENDEKATAN SISTEM PAKAR. 1-9.

Irfan, M., Jusak, \& Saskianti, T. (2015). Rancang Bangun Sistem Pakar Identifikasi Penyakit Gigi Berbasis Web Dengan Menggunakan Metode Certainty Factor. Jsika, 4(2), 1-10. Retrieved from http://jurnal.stikom.edu/index.php/jsika/article/ viewFile/864/479

Lie, A., Santoso, K. W., \& Sukartono, Ardesnando, W. (2013). SISTEM PAKAR UNTUK MENDIAGNOSA PENYAKIT GIGI DENGAN TEOREMA BAYES. SISTEM PAKAR UNTUK MENDIAGNOSA PENYAKIT GIGI DENGAN TEOREMA BAYES, 1-8.

Mulyani, E. D. S., \& SM, N. N. F. (2017). APLIKASI PAKAR DIAGNOSA PENYAKIT GIGI MENGGUNAKAN METODE FORWARD CHAINING BERBASIS MOBILE. 119-124.

Musrifah, A., \& Mutia, E. (2017). PEMBUATAN APLIKASI PENGELOLAAN PROPOSAL DI UNIT KEGIATAN PENGELOLA (UPK) KECAMATAN MANDE BERBASIS DESKTOP. Media Jurnal Informatika, 9(1), 28-36.

Pranata, D., Hamdani, \& Marisa, K. D. (2015). RANCANG BANGUN WEBSITE JURNAL ILMIAH BIDANG KOMPUTER (STUDI KASUS : PROGRAM STUDI ILMU KOMPUTER UNIVERSITAS MULAWARMAN). Jurnal Informatika Mulawarman, 10(2), 25-29.

Syifani, D., \& Dores, A. (2018). APLIKASI SISTEM REKAM MEDIS DI PUSKESMAS KELURAHAN GUNUNG. APLIKASI SISTEM REKAM MEDIS DI PUSKESMAS KELURAHAN GUNUNG Dita, 9(September 2018), 22-31.

Tuslaela, \& Permadi, D. (2018). SISTEM PAKAR DIAGNOSA PENYAKIT GIGI DAN MULUT BERBASIS WEB DENGAN METODE FORWARD CHAINING. Jurnal PROSISKO Vol. 5, 5(1), 17-26. Retrieved from http://ejurnal.lppmunsera.org/index.php/PROSISKO/a rticle/view/586/594
Umar, U. (2015). Perancangan sistem informasi administrasi kesiswaan pada madrasah aliyah miftahul jannah dengan metodologi berorientasi objek. 1-8.

Widodo, M. R. R., Zainuddin, M. R., \& Laura, S. N. (2016). Sistem Informasi Dan Pengolahan Data Kursus Mobil Berbasis Web Dengan Sms Gateway Di Armada Pasuruan. Informatika Merdeka Pasuruan, 1(3), 85-104. Retrieved from http://ejurnal.unmerpas.ac.id/index.php/inform atika/article/view/43

Yusuf, R., Kusniyati, H., \& Nuramelia, Y. (2016). APLIKASI DIAGNOSIS GANGGUAN KECEMASAN MENGGUNAKAN METODE FORWARD CHAINING BERBASIS WEB DENGAN PHP DAN. 9(1), 1-13. 